\title{
FOR THE SAKE OF ABSTRACT VALUES
}

Since the publication of the Blue Jay is only one of the projects of the Saskatchewan Natural History Society, we often find ourselves thinking of the Society's other roles. In recent years, our organization has directed part of its energy and enthusiasm toward the preservation of natural wildernes's. In December, 1965, for example, a brief was presented to the Government of Saskatchewan urging the establishing of a wilderness area in the Pasquia Hills, southeast of La Ronge. And it is not only through the efforts of executive officers that such a cause is promoted; perhaps the most valuable support comes from the personal conviction of individual members that wild lands have an inherent value because they are wild lands. In a letter in this number of the Blue Jay, a member from Norway House, Manitoba, tells how a canoe trip brought him a deep appreciation of the meaning of wilderness. When we try to define the real issue, however, it is not easy to find meaningful words. For this reason, our imagination was struck by the forthright statement made by Archie Carr in The Reptiles (by Archie Carr and the Editors of Life, 1963) :

"No significant preserving of nature can be done with slight sacrifice. The true test will come when great sacrifices are needed, when it becomes necessary to fight the indifference of most of the world and the active opposition of much of it, to surmount man's ingrained determination to put the far future out of his mind in matters of current profit.

"Besides the inherent technical difficulties of wilderness conservation, the effort to save original nature faces a whole constellation of other kinds of problems. The easiest obstacle to recognize is the opposition by people who oppose the keeping of wildernes's for material reasons. These people would shape the world into an ant hill; they are clearly mad. It is unthinkable that they will much longer control the destiny of the race. There is another block of humanity that simply does not care; and an unsorted lot who think of themselves as conservationists, and who in one way or another are, but who are not facing the really tough obligation at all. I refer to all people who think of saving nature for meat, water, timber or picnic grounds for the future; and to the hunters who hope their grandsons will get red blood by shooting things, and to the reverence-for-life cultists who are foredoomed to inconsistency, and to the biologists who resist the loss of material for study, and to keepers of zoological gardens who preserve nature in cages. Putting this mixture of motives and aspirations together under the label conservation has made, in some cases, a temporarily stronger front. But it has muddied the real issue, hidden the dimensions of the long job and kept everybody from articulating the awful certainty that the hard saving has got to be done for the sake of abstract values."

Cover photograph: David Chandler, and his sister Ruth, mutually enjoying a view looking north over the Frenchman River valley in southwestern Saskatchewan. Prairie dogs occur in the valley flats. It is in this area also that the Poor-will, a smaller version of the Common Nighthawk, has recently been found (see p.7). 